\title{
Pembelajaran Efektif dalam Pengajaran Bahasa Arab Tingkat Menengah
}

\author{
Basri Mahmud ${ }^{1}$, Hamzah $^{2}$ \\ ${ }^{1}$ Institut Agama Islam DDI Polewali Mandar, Sulawesi Barat \\ 1 e-mail: basri141mahmud@gmail.com \\ ${ }^{2}$ Institut Agama Islam DDI Polewali Mandar, Sulawesi Barat \\ 2 e-mail: hamzah87_aziz@ymail.com
}

\begin{abstract}
Not a few Arabic teachers complain about their role as teachers and the ineffectiveness of their learning that has been done in the classroom. Many of the things that can cause this, among them because of their ignorance of the concept of effective and efficient learning, how to streamline a learning and also manage a learning, so that learning is carried out is only the transfer of knowledge (knowledge transfer) without full consideration of the goals set. In addition, teachers also lack variety of learning methods and strategies. This paper aims to uncover conceptually about effective and efficient learning in teaching Arabic at the secondary level; how indicators, principles and urgency in a learning so that teachers especially Arabic teachers know how to make an effective learning course with the realization of the goals set.
\end{abstract}

Keywords: Pembelajaran efektif, pembelajaran efisien, pengajaran bahasa Arab

\begin{abstract}
Abstrak
Tidak sedikit para guru bahasa Arab mengeluhkan peran mereka sebagai guru dan ketidakefektifan pembelajaran mereka yang telah dilakukan di dalam kelas. Banyak diantara hal yang bisa menyebabkan hal demikian, diantaranya karena ketidaktahuan mereka tentang konsep pembelajaran efektif dan efisien, cara mengefektifkan sebuah pembelajaran dan juga mengatur sebuah pembelajaran, sehingga pembelajaran yang dilakukan hanya bersifat transfer pengetahuan (knowledge transfer) tanpa penuh pertimbangan terhadap tujuan yang telah ditetapkan. Di samping itu, guru juga kurang menguasai metode dan strategi pembelajaran secara variatif. Tulisan ini bertujuan untuk mengungkap secara konseptual tentang pembelajaran efektif dan efisien dalam pengajaran bahasa Arab tingkat menengah; bagaimana indikator, prinsip dan urgensinya dalam sebuah pembelajaran sehingga para guru khususnya guru bahasa Arab mengetahui cara mengefektifkan sebuah pembelajaran tentunya dengan realisasi tujuan yang telah ditetapkan.
\end{abstract}

Kata Kunci: Pembelajaran efektif, pembelajaran efisien, pengajaran bahasa Arab 


\section{Pendahuluan}

Terdapat delapan Standar Nasional Pendidikan ${ }^{1}$ yang dijadikan acuan standar mutu pembelajaran bahasa Arab di seluruh wilayah hukum Negara Kesatuan Republik Indonesia yang diatur dalam Peraturan Pemerintah RI sebagai kriteria minimal tentang sistem pendidikan. Salah satu diantaranya adalah Standar Proses. Standar tersebut merupakan salah satu dari tiga komponen utama yang menjadi perhatian dalam proses manajemen mutu sebuah pembelajaran bahasa Arab di Madrasah.

Artinya bahwa seorang pendidik atau guru yang menjadi ujung tombak dan eksekutor mempunyai andil, peranan yang sangat besar dan tanggung jawab dalam mengefektifkan sebuah proses pembelajaran serta mewujudkan kompetensi lulusan ${ }^{2}$ secara efektif dan efisien. Dalam hal ini, guru adalah aktor utama kesuksesan pendidikan yang telah dicanangkan. Tanpa keterlibatan aktif seorang guru, pendidikan kosong dari materi, esensi dan substansi.

Di antara dilema yang dialami oleh sebahagian para guru adalah belum efektifnya proses pembelajaran yang telah diajarkan, yang terkadang bertumpu dan buntu disekitar alokasi waktu mata pelajaran bahasa Arab yang kurang, manajemen kelas, metode dan strategi pembelajaran yang kurang dikuasai. Bahkan Jamal Ma'mun Asmani mensinyalir bahwa guru yang ada di negeri ini belum mencerminkan diri sebagai guru yang ideal dan inovatif yang siap mendidik siswa dengan profesionalisme dan optimisme. Kapasitas intelektual yang rendah, kedisiplinan yang lemah, semangat belajar yang hampir hilang, integritas moral yang sering menyeleweng dan dedikasi sosial yang rendah, miskin kreatifitas dan inovatif adalah sebagian potret buram guru. ${ }^{3}$

Seorang pendidik yang bermutu adalah pendidik yang mengenal berbagai macam metodologi pengajaran, agar proses pembelajaran berjalan secara variatif, sehingga guru dan peserta didik sama-sama semangat dalam menjalani proses pembelajaran dan mencapai tujuan pembelajaran yang telah dirumuskan dalam bentuk Rencana Pelaksanaan Pembelajaran.

Di samping itu, dalam proses pembelajaran bahasa Arab, guru juga dituntut untuk berperan aktif, kreatif dan inovatif agar pembelajaran menjadi menyenangkan dan efektif dan akhirnya membuahkan kualitas penguasaan bahasa yang baik dan benar.

Tulisan sederhana ini, akan mencoba memaparkan sekelumit tentang konsep pembelajaran efektif dalam pembelajaran bahasa Arab untuk tingkat menengah.

\section{Pengertian Pembelajaran Efektif}

Pembelajaran berasal dari kata belajar yang mendapat imbuhan pem dan akhiran an, yang berarti upaya untuk belajar. Kegiatan ini akan mengakibatkan peserta didik mempelajari sesuatu dengan cara efektif dan efisien. ${ }^{4}$ Jos Daniel Parera sejalan dengan Nababan dalam

\footnotetext{
${ }^{1}$ Delapan Standar Nasional Pendidikan tersebut adalah: Standar Isi, Standar Proses, Standar Kompetensi Lulusan, Standar Pendidik dan Tenaga Kependidikan, Standar Sarana Prasarana, Standar Pengelolaan Madrasah, Standar Pembiayaan, dan Standar Penilaian Pendidikan. Peraturan Pemerintah RI Nomor 19 tahun 2005 tentang Standar Nasional Pendidikan.

2 Adapun kompetensi lulusan bahasa Arab yang dimaksud adalah menyimak (al-istima'), berbicara (al-kalam), membaca (al-qira'ah), dan menulis (al-kitabah) sebagimana tertuang dalam keputusan Menteri Agama nomor 165 tahun 2014. 2010), h. 138.

3 Jamal Ma'mur Asmani, Tips Menjadi Guru Inspiratif, Kreatif dan Inovatif, (Cet. VI; Jogjakarta: DIVA Press,

${ }^{4}$ Muhaimin, dkk., Strategi Belajar Mengajar, (Surabaya: CV. Citra Media, 1996), h. 99.
} 
memberikan defenisi pembelajaran yaitu nominalisasi proses untuk bentuk membelajarkan, artinya proses membuat atau menyebabkan orang lain belajar, dan pembelajar adalah guru atau orang yang membuat orang lain belajar. ${ }^{5}$

Sementara Oemar Hamalik secara detail mendefinisikan Pembelajaran sebagai suatu kombinasi yang tersusun meliputi unsur-unsur manusiawi (guru, peserta didik, dan selainnya), material (buku, papan tulis, dan selainnya), fasilitas dan perlengkapan (ruang kelas dan audio visual dan selainnya), dan prosedur (jadwal dan metode penyampaian informasi) yang saling mempengaruhi untuk mencapai tujuan pembelajaran. ${ }^{6}$ Lebih lanjut, Salehuddin Yasin menyimpulkan bahwa pembelajaran sebagai suatu proses instruksional yang terstruktur dalam artian prosesnya terkait dengan suatu rangkaian komponen pembelajaran yang saling terkait satu dengan yang lain menuju pencapaian tujuan instruksional yang telah digariskan sebelumnya. ${ }^{7}$

Sedangkan kata efektif, dalam Kamus Bahasa Indonesia berarti ada efeknya, pengaruhnya, akibatnya, kesannya atau dapat membawa hasil dan berhasil guna. ${ }^{8}$ Jika mengutip istilah yang digunakan oleh Reigeluth dalam pembelajaran, itu mengarah pada terukurnya suatu tujuan dari belajar. ${ }^{9}$ Menurut Supardi, kata efektifitas berarti berusaha untuk dapat mencapai sasaran yang telah ditetapkan sesuai dengan kebutuhan yang diperlukan, sesuai pula dengan rencana, baik dalam penggunaan data, sarana, maupun waktunya atau berusaha melalui aktifitas tertentu baik secara fisik maupun non fisik untuk memperoleh hasil maksimal baik secara kuantitatif maupun kualitatif. ${ }^{10}$

Adapun menurut Poerwadarminto dalam Supardi bahwa di dalam pengajaran, efektifitas berkenaan dengan pencapaian tujuan, dengan demikian analisis tujuan merupakan kegiatan pertama dan dalam perencanaan pengajaran. Jadi, efektifitas adalah keterkaitan antara tujuan dan hasil yang dinyatakan, dan menunjukkan derajat kesesuaian antara tujuan yang dinyatakan dengan hasil yang dicapai.

Istilah lain yang menunjukkan efektifitas adalah kata efisien. Yaitu dalam Kamus Bahasa Indonesia berarti tepat atau sesuai untuk melakukan (menghasilkan) sesuatu dengan tidak membuang-buang waktu dan tenaga dan biaya, atau mampu menjalankan tugas dengan tepat dan cermat, berdaya guna atau tepat guna. ${ }^{11}$

Kata efektif dan efesien merupakan dua kata yang yang saling terkait dalam menunjang keberhasilan proses pembelajaran. Kata efektif lebih mengarah kepada pencapaian tujuan, sedangkan kata efisien lebih mengarah kepada penggunaan waktu. Sehingga secara tersirat dapat dipahami bahwa efisiensi merupakan di antara berbagai indikator dalam pembelajaran yang efektif.

\footnotetext{
${ }^{5}$ Jos Daniel Parera, Linguistik Edukasional: Metodologi Pembelajaran Bahasa, Analisis Kontranstif Antar Bahasa, Analisis Kesalahan Berbahasa, (Ed. II; Jakarta: Erlangga, 1997), h. 24-25.

${ }^{6}$ Oemar Hamalik, Kurikulum dan Pembelajaran, (Jakarta: Bumi Aksara, 1995), h. 57.

${ }^{7}$ Salehuddin Yasin, Metode Belajar dan Pembelajaran yang Efektif, dalam Jurnal Adabiyyah. Volume 12, Nomor 1, 2012. 1-9, h. 2.

${ }^{8}$ Tim Penyusun Kamus Pusat Bahasa, Kamus Bahasa Indonesia, (Jakarta: Pusat Bahasa, 2008), h. 374.

${ }^{9}$ Hamzah B. Uno dan Nurdin Mohamad, Belajar dengan Pendekatan PAILKEM, (Cet. II; Jakarta: Bumi Aksara, 2011), h. 173.

${ }^{10}$ Supardi, Sekolah Efektif: Konsep Dasar dan Praktiknya, (Jakarta: Rajawali Pers, 2013), h. 163.

${ }^{11}$ Tim Penyusun Kamus Pusat Bahasa, Kamus Bahasa Indonesia, h. 374.
} 
Berdasarkan pengertian tersebut di atas, maka bisa disimpulkan bahwa pembelajaran efektif adalah suatu proses pembelajaran holistik yang diarahkan disamping untuk perubahan prilaku (behavior) peserta didik ke arah yang lebih baik berdasarkan potensi dan perbedaan yang dimilikinya, melainkan juga menuju pencapaian tujuan instruksional pembelajaran yang telah digariskan sebelumnya secara terukur dan efisien. Kalau konteksnya dibawa ke dalam ranah pengajaran bahasa Arab, maka tujuan standar instruksional yang dimaksud adalah tujuan kompetensi lulusan bahasa Arab yang empat yaitu kemampuan menyimak (al-istima'), berbicara (al-kalam), membaca (al-qira'ah), dan menulis (al-kitabah).

Sedangkan Ali al-Khuliy mendefinisikan pembelajaran efektif sebagai pembelajaran yang efisien dengan tercapainya tujuan atau ukuran yang melebihi dari apa yang telah direncanakan. $^{12}$

\section{Konsep Pembelajaran Efektif dalam Pengajaran Bahasa Arab Tingkat Menengah}

Setelah mengetahui makna atau defenisi pembelajaran efektif tersebut, maka tentunya kita ingin mengetahui seperti apa konsep, baik kriteria maupun prasyarat yang masuk kategori pembelajaran efektif dan efisien dalam pengajaran bahasa Arab, dan bagaimana kita dapat menentukan pembelajaran tersebut efektif dan efisien.

\section{Indikator Pembelajaran yang efektif}

Wotruba dan Wright mengidentifikasi tujuh indikator yang dapat menunjukkan pembelajaran efektif berdasarkan pengkajian dan hasil penelitian ${ }^{13}$, sebagai berikut:

a. Pengorganisasian materi yang baik

Pengorganisasian materi terdiri dari; perincian materi, urutan materi dari yang mudah ke yang sukar, dan kaitannya dengan tujuan. Faktor lain yang perlu dipertimbangkan dalam penyajian materi adalah bagaimana kemampuan daya serap peserta didik dan penggunaan media, sikap, metode mengajar dan cepat lambat penyajian. Kemampuan tersebut bertalian erat dengan motivasi dan kesiapan belajar mereka, dan kesiapan belajar individu ditentukan oleh pengetahuan pelajaran yang telah dipelajari sebelumnya, keterampilan membaca dan mendengar, tingkat pendidikan yang dicapai dan tingkat kesulitan materi.

Pengorganisasian materi untuk setiap pertemuan secara umum selalu dibagi dalam tiga bagian tahapan proses pembelajaran, yaitu kegiatan pendahuluan, kegiatan inti atau kegiatan pelaksanaan, dan kegiatan penutup. Berikut uraian tentang model tahapan mengajar.

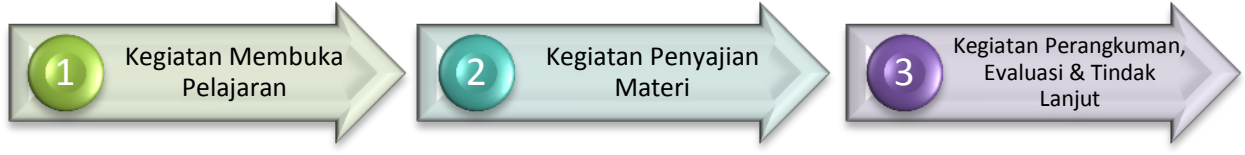

12 Muhammad Ali al-Khuliy, Asalib Tadris al-Lughah al-'Arabiyyah, (Cet. III; Riyadh: al-Mamlakah al'Arabiyyah al-Sa'udiyyah, 1989), h. 31.

${ }^{13}$ Hamzah B. Uno dan Nurdin Mohamad, Belajar dengan Pendekatan PAILKEM, h. 174. 
b. Komunikasi yang efektif

Kemampuan berkomunikasi tidak hanya diwujudkan lewat penjelasan secara verbal, akan tetapi bisa juga melalui tulisan lewat penggunaan media atau teknik dan strategi yang menarik perhatian peserta didik.

c. Penguasaan dan antusiasme terhadap materi pelajaran

Seorang guru dituntut untuk menguasai materi pelajaran dengan benar agar materi bisa diorganisasikan secara sistematis dan logis. Seorang guru harus mampu menghubungkan materi yang diajarkan dengan pengetahuan yang telah dimiliki oleh para peserta didiknya dan mampu mengaitkan materi secara konstruktif sehingga proses pembelajaran hidup dan tidak monoton. Penguasaan materi dan pemberian pengetahuan tidak cukup akan tetapi seorang guru juga harus mampu memberikan keterampilan kepada para peserta didik.

d. Sikap positif terhadap peserta didik

Sikap positif terhadap peserta didik bisa tercermin dalam beberapa cara, yaitu:

- Apakah seorang memantau perhatian peserta didiknya?

- Apakah seorang guru memberikan bantuan jika peserta didiknya mengalami kesulitan dalam memahami materi yang diajarkan?

- Apakah seorang guru mendorong para peserta didiknya untuk terlibat secara aktif seperti dalam mengajukan pertanyaan atau memberi respon atau pendapat?

- Apakah seorang guru memberikan penguatan atau ganjaran terhadap respon peserta didiknya yang tepat?

- Apakah seorang guru dapat dihubungi diluar jam pelajaran?

- Apakah seorang guru menyadari atau peduli dengan apa yang dipelajari oleh peserta didiknya?

e. Pemberian nilai yang adil

Sejak awal peserta didik bisa di informasikan berbagai macam penilaian yang akan dilakukan, seperti tes formatif, makalah, tugas, tes akhir dan pertanyaan lainnya yang mempunyai kontribusi terhadap nilai akhir. Keadilan dalam pemberian nilai tercermin dari adanya:

- Kesesuaian soal tes dengan materi yang diajarkan

- Sikap konsisten terhadap pencapaian tujuan pembelajaran

- Usaha yang dilakukan dalam mencapai tujuan

- Kejujuran siswa dalam memperoleh nilai

- Pemberian umpan balik (feed back) terhadap hasil pekerjaan peserta didik.

f. Keluwesan dalam pendekatan pembelajaran (variety)

Salah satu petunjuk adanya semangat dalam mengajar menurut Barlow adalah dengan pendekatan pembelajaran yang variatif. ${ }^{14}$ Variasi seorang guru menurut Supardi, tidak hanya pendekatan akan tetapi meliputi berbagai variasi

\footnotetext{
${ }^{14}$ Hamzah B. Uno dan Nurdin Mohamad, Belajar dengan Pendekatan PAILKEM, h. 189.
} 
metode mengajar, berbagai strategi bertanya, memberikan reinforcement dengan berbagai cara dan berbagai tipe media pembelajaran yang akan dipergunakan. ${ }^{15}$

Karakteristik peserta didik yang berbeda, kendala yang berbeda menghendaki pendekatan yang berbeda pula. Dengan kata lain, kegiatan pembelajaran seharusnya dtentukan berdasarkan karakteristik peserta didik, mata pelajaran, dan kendala yang dihadapi. Sehingga peserta didik memperoleh pelayanan yang sesuai dengan kemampuan mereka.

g. Hasil belajar peserta didik yang baik

Untuk mengukur sejauh mana penguasaan dan keterampilan yan telah dicapai peserta didiknya, maka seorang guru berkewajiban untuk memberikan penilaian terhadap hasil belajar dan mengevaluasinya. Menurut W.J. Kripsin dan Feldhusen bahwa evaluasi merupakan satu-satunya cara untuk menentukan ketepatan pembelajaran dan keberhasilan. Sehingga indikator pembelajaran efektif dapat diketahui dari hasil belajar peserta didik yang baik. Petunjuk keberhasilan belajar peserta didik dapat dilihat melalui penguasaan materi pelajaran yang telah diberikan. Adapun kunci pokok untuk memperoleh ukuran dan data hasil belajar adalah dengan menetapkan indikator dikaitkan dengan prestasi yang diukur. ${ }^{16}$

Sementara Slavin menetapkan empat unsur utama dalam pembelajaran yang efektif yang disebut sebagai QAIT yaitu Quality (mutu pengajaran), Appropriateness (kesesuaian tingkat pengajaran), Incentive (insentif), Time (waktu). ${ }^{17}$

Dalam hal waktu, proses pengajaran dipengaruhi oleh dua faktor waktu; pertama: allocated time yaitu waktu yang telah ditetapkan oleh pihak sekolah yang diperuntukkan kepada guru untuk mengajarkan sebuah mata pelajaran. Kedua: engaged time atau time on task yaitu waktu yang dipergunakan oleh seorang guru untuk mengajar dan peserta didik untuk belajar.

Efisiensi dalam proses pembelajaran terletak pada pengelolaan waktu tersebut, bagaimana seorang guru mengelola dan mengatur waktu yang diperlukan dalam pembelajaran untuk dirinya dan untuk peserta didiknya sehingga proses pembelajaran efisien dan efektif.

Salehuddin Yasin menegaskan bahwa penggunaan waktu menjadi di antara poin penting dalam memastikan berlangsung tidaknya proses pembelajaran dalam upaya mencapai hasil yang efektif. Adapun indikator-indikator tersebut adalah sebagai berikut:

a. Kesiapan subjek belajar dalam artian telah memiliki dan berada dalam suasana psikologis yang mantap dan tidak dalam keadaan labil atau kurang menentu.

b. Bahan yang akan dipelajari benar-benar mempunyai tingkatan yang diutamakan pada saat itu sehingga kepadanya tertuju segala perhatian atau konsentrasi.

\footnotetext{
${ }^{15}$ Supardi, Sekolah Efektif: Konsep Dasar dan Praktiknya, h. 166-167.

${ }^{16}$ Hamzah B. Uno dan Nurdin Mohamad, Belajar dengan Pendekatan PAILKEM, h. 190. Supardi, Sekolah Efektif: Konsep Dasar dan Praktiknya, h. 168.

${ }^{17}$ Supardi, Sekolah Efektif: Konsep Dasar dan Praktiknya, h. 170-172.
} 
c. Alat bantu yang memadai tersedia guna terjadinya proses belajar secara normal terutama aspek lingkungan belajar yang bila perlu menekan semaksimal mungkin adanya gangguan yang akan memecah perhatian subjek belajar.

d. Penggunaan waktu belajar yang efisien dalam artian hasil yang ingin dicapai secara terukur dapat dibandingkan dengan jumlah waktu yang dihabiskan untuk itu.

e. Tingkat kepuasan jiwa dalam menghadapi perubahan yang cukup berarti sebagai salah satu hasil belajar secara kualitatif didapatkan dari proses tersebut. ${ }^{18}$

Sedangkan Ali al-Khuliy, secara sederhana mengutarakan 12 poin syarat terpenuhinya disebut sebagai pembelajaran efektif, yaitu:

a. Guru harus mengetahui metodologi pembelajaran, terlebih kepada seorang pengajar bahasa Arab sebagai bahasa kedua/asing, mulai dari pemelihan pendekatan, metode, strategi, dan pengevaluasian dalam membelajarkan keterampilan berbahasa.

b. Seorang guru tidak hanya dituntut sebagai tenaga pengajar akan tetapi juga sebagai tenaga pendidik yang menjadi teladan dan panutan buat peserta didiknya.

c. Seorang guru juga suaranya harus jelas saat menerangkan. Karena suara rendah dan tidak jelas mempengaruhi konsentrasi peserta didik yang mengakibatkan sulit untuk mengikuti arahan sang guru.

d. Guru harus menguasai bahan yang diajarkan. Tidak diperbolehkan berpikir tiba masa tiba akal terlebih lupa dan tidak tahu apa yang harus diajarkan.

e. Wawasan keilmuan guru luas.

f. Guru juga diharuskan menjadi seorang motivator terhadap peserta didiknya dan menghargai pekerjaannya lewat reward atau hadiah sehingga termotivasi untuk belajar.

g. Guru tidak pilih kasih terhadap peserta didik dalam proses pembelajaran.

h. Interaksi seorang guru terhadap peserta didiknya menyejukkan dengan penuh kesantunan dan ramah.

i. Guru menguasai manajemen pengaturan kelas

j. Guru bersikap adil terhadap peserta didik

k. Guru perhatian dan respect terhadap peserta didik dan meminimalisir rasa kesal dan benci terhadapnya agar tak berakibat kepada rasa benci terhadap guru dan mata pelajarannya.

1. Adanya keterlibatan siswa, bahkan aktif dalam proses pembelajaran. ${ }^{19}$

Al-Qabisi lebih lanjut melihat bahwa indikator pembelajaran yang sukses itu ada pada peranan seorang guru. Guru menjadi posisi sentral dalam proses pembelajaran. Dalam pembelajaran bukan satu-satunya aspek kognitif yang menjadi tolak ukur melainkan juga ranah afektif peserta didik. Sehingga ia menyarankan bahwa seorang

\footnotetext{
${ }^{18}$ Salehuddin Yasin, Metode Belajar dan Pembelajaran yang Efektif, dalam Jurnal Adabiyyah., h. 6.

${ }^{19}$ Muhammad Ali al-Khuliy, Asalib Tadris al-Lughah al-'Arabiyyah, h. 32-33.
} 
guru tidak hanya menjadi tenaga pengajar untuk mentrasnfer ilmunya ${ }^{20}$ melainkan juga menjadikan dirinya sebagai contoh dan teladan (tenaga pendidik) buat peserta didiknya sebagai pendekatan untuk menyentuh dan merubah tingkah laku mereka. ${ }^{21}$

Di samping itu, ia juga menyarankan agar mendidik dengan cara yang santun bahkan dalam memberikan hukuman pun juga harus santun atas dasar mendidik bukan atas dasar unsur dendam dan berlaku kasar. Karena hukuman yang bersifat kasar dan balas dendam terkesan buruk baik secara fisik maupun psikis. Seorang guru juga dilarang menghukum peserta didik dengan cara menghalanginya untuk tidak makan ataupun istirahat. $^{22}$

Sedangkan al-Dailamiy dan al-Wailiy, lebih melihat pembelajaran yang sukses dan efektif itu kepada pemilihan guru terhadap metode pengajaran. Karena metode yang baik itu bisa meminimimalisir bahkan memperbaiki kelemahan-kelemahan yang biasa terjadi dalam pembelajaran, seperti kurikulum yang kurang bagus, kelemahan pembelajar dan kesulitan buku atau bahan ajar. Tentunya pemilihan metode pengajaran itu, banyak hal dan faktor-faktor yang mempengaruhi sukses dan efektif atau tidaknya. Seperti kompetensi guru, motivasi guru, kepribadian guru, kecenderungan psesrta didik dalam belajar, kecerdasan dan umur peserta didik, jumlah peserta didik dalam satu kelas dan tujuan pembelajaran. ${ }^{23}$

\section{Prinsip-prinsip belajar pada pembelajaran yang efektif}

Hamzah B. Uno memberikan delapan prinsip dasar secara umum dan implikasinya pada pembelajaran efektif, sebagai berikut:

\section{a. Perhatian (attention)}

Menurut Gage dan Berliner dalam Hamzah B. Uno bahwa Peranan perhatian sangat penting dimiliki oleh peserta didik karena kajian dari teori belajar pengolahan informasi terungkap bahwa tanpa adanya perhatian dari peserta didik tak mungkin terjadi aktifitas belajar. Dalam proses pembelajaran terdapat 2 macam tipe perhatian, yaitu perhatian terpusat dan perhatian terbagi.

b. Motivasi (motivation)

Slavin mengatakan bahwa motivasi merupakan salah satu prasyarat yang paling penting dalam belajar. Motivasi merupakan faktor penting dalam menentukan keberhasilan belajar. Bila tidak ada motivasi maka proses

${ }^{20}$ Prof. Dr. S. Nasution menyanggah tentang guru yang hanya kerjanya mentransfer ilmunya. Ia mengutarakan dalam bukunya Didaktik Asas-asas Mengajar, bahwa guru tidak disebut mengajar apabila kerjanya hanya mentransfer ilmu, atau hanya menyuruh anak menghafal. Itu kurang tepat untuk dikata sebagai mengajar. Mengajar tidak hanya persoalan tersebut, tetapi mengajar itu lebih dari pada itu, yaitu membimbing, membantu anak berkembang dan menyesuaikan diri kepada lingkungan. Konsekwensi mengajar itu dan dikatakan berhasil apabila anak-anak belajar sebagai akibat usahanya. Lihat S. Nasution, Didaktik Asas-asas Mengajar, (Cet. I; Jakarta: Bumi Aksara, 1995), h. 5-7.

${ }^{21}$ Ahmad Fuad al-Ahwani, al-Tarbiyyah al-Islamiyyah aw al-Ta'lim fi Ra'yi al-Qabisi, (Kairo: Dar Ihya al-Kutub al-‘Arabiyyah, 1955), h. 181.

22 Ahmad Fuad al-Ahwani, al-Tarbiyyah al-Islamiyyah aw al-Ta'lim fi Ra'yi al-Qabisi, h. 126. Muslim, Konfigurasi Pemikiran Al-Qabisi tentang Pendidikan Islam, dalam Potensia: Jurnal Kependidikan Islam. Volume 2, Nomor 2, 2016. 199-211., h. 208-209.

${ }^{23}$ Thaha Ali Husain al-Dailamiy dan Sa'ad Abdu al-Karim al-Wailiy, al-Lughah al- 'Arabiyyah: Manahijuha wa Tharaiq Tadrisiha, (Cet. II; Oman: Dar al-Syuruq, 2005), h. 88-89. 
pembelajaran tidak akan terjadi, dan motivasi dapat mempengaruhi proses dan hasil belajar. Wlodkwosky mengatakan bahwa motivasi yang dimiliki dan dibawa oleh peserta didik berpengaruh kuat terhadap apa dan bagaimana mereka belajar.

Sebagai suatu hasil, motivasi merupakan hasil dari pembelajaran yang efektif. Jika pembelajarn efektif, menarik, bermanfaat, dan sesuai dengan minat dan kebutuhan peserta didik, maka akan meningkatan keterlibatan siswa dalam proses pembelajaran. ${ }^{24}$

Hamzah B. Uno mengutarakan bahwa ada 4 peranan penting motivasi dalam pembelajaran, yaitu peran motivasi dalam menentukan penguatan belajar, peran motivasi dalam menentukan ragam kendali terhadap ransangan belajar, peran motivasi dalam memperjelas tujuan belajar, dan peran motivasi dalam menentukan ketekunan belajar. ${ }^{25}$

c. Keaktifan (active)

Belajar hanya memungkinkan terjadi apabila peserta didik aktif dan mengalaminya sendiri. John Dewey mengemukakan bahwa belajar adalah menyangkut apa yang harus dikerjakan peserta didik untuk dirinya sendiri. Dengan demikian, inisiatif harus datang dari peserta didik itu sendiri, peran guru sebagai pembimbing dan pengarah.

d. Keterlibatan langsung (direct performance)

Edgar Dale mengklasifikasi penggolongan pengalaman belajarnya dalam bentuk kerucut. Ia menempatkan bahwa belajar yang paling baik adalah melalui pengalaman langsung. Dalam belajar, peserta didik tidak hanya mengamati, tetapi harus menghayati, terlibat langsung dan bertanggung jawab terhadap proses dan hasilnya.

e. Pengulangan (practice)

Bell mengutarakan bahwa pengulangan merupakan prinsip belajar yang berpedoman pada pepatah "practice makes perfect". Dengan pengulangan maka daya-daya yang ada pada individu seperti mengamati, memegang, mengingat, menghayal, merasakan dan berpikir akan berkembang. Grage dan Berliner mengatakan bahwa salah satu strategi belajar yang bisa diterapkan adalah metode drill yaitu bentuk belajar yang menerapkan prinsip pengulangan.

f. Tantangan

Teori medan yang dikemukakan oleh Kurt Lewin mengatakan bahwa sesungguhnya peserta didik yang sedang belajar berada dalam suatu medan lapangan psikologis. Siswa menghadapi tujuan yang harus dicapai, tetapi untuk mencapainya selalu ada tantangan yang harus dihadapi. Namun ada motif yang bisa mengatasi tantangan tersebut, yaitu motivasi belajar terhadap peserta didik agar dapat mengatasinya.

\footnotetext{
${ }^{24}$ Hamzah B. Uno dan Nurdin Mohamad, Belajar dengan Pendekatan PAILKEM, h, 194.

${ }^{25}$ Hamzah B. Uno, Teori Motivasi \& Pengukurannya: Analisis di Bidang Pendidikan, (Cet. II; Jakarta: Bumi Aksara, 2007), h. 27-28.
} 


\section{g. Penguatan (reinforcement)}

Gage dan Berliner mengatakan bahwa peserta didik merasa lebih bersemangat apabila mengetahui akan mendapatkan hasil feedback yang menyenangkan. Akan tetapi dorongan belajar menurut B.F. Skinner bukan hanya yang menyenangkan melainkan positif (operant conditioning) dan negatif (escape conditioning) dapat memperkuat belajar.

h. Perbedaan individual

Perbedaan individual berpengaruh pada cara dan hasil belajar peserta didik. Dengan demikian, perbedaan tersebut perlu diperhatikan oleh seorang guru. Disinilah letak peran penggunaan metode, strategi, media yang variatif yang digunakan oleh seorang guru untuk membantu melayani mengakomodir perbedaan karakterisitik dan kemampuan peserta didik dalam proses pembelajaran. ${ }^{26}$

Menurut Supardi dalam buku Sekolah Efektif, bahwa terdapat 11 prinsip dalam pembelajaran efektif, yaitu:

a. Berpusat pada peserta didik

b. Pembalikan makna belajar

c. Belajar dengan melakukan

d. Mengembangkan kemampuan sosial, kognitif dan emosional

e. Mengembangkan keingintahuan, imajinasi dan fitrah bertuhan

f. Mengembangkan keterampilan pemecahan masalah

g. Mengembangkan kreatifitas peserta didik

h. Mengembangkan kemampuan menggunakan IPTEK

i. Menumbuhkan kesadaran sebagai warga negara yang baik

j. Belajar sepanjang hayat

k. Perpaduan kemandirian/ Keterpaduan kompetensi, solidaritas dan kerjasama. ${ }^{27}$

Apabila ditarik ke ranah pembelajaran bahasa Arab secara khusus, disamping memperhatikan prinsip-prinsip dasar tersebut di atas, maka ada lima prinsip dasar dalam pembelajaran bahasa Arab sebagaimana yang disarankan oleh Kamal Ibrahim Badri dan Mamduh Nuruddin dalam Amrah Kasim, yaitu:

a. Prinsip prioritas (أولويات التقديم)

Artinya seorang guru hendaknya memperhatikan urutan dan mengorganisasikan materi-materi ajar yang akan diajarkan. Seperti medahulukan kemampuan istima' dan kalam dari pada kemampuan kitabah dan qira'ah, mengajarkan yang pokok sebelum pelengkap, mengajarkan kosakata yang berfaedah dan kontekstual dari pada kosakata yang jauh dari konteks, dan lain-lain.

b. Prinsip bertahap (التدرج)

Artinya seorang guru hendaknya membelajarkan secara bertahap, mulali dari yang mudah ke yang sulit, yang ma'lum ke yang majhul, dan lain-lain.

\footnotetext{
${ }^{26}$ Hamzah B. Uno dan Nurdin Mohamad, Belajar dengan Pendekatan PAILKEM, h. 196-197.

${ }^{27}$ Supardi, Sekolah Efektif: Konsep Dasar dan Praktiknya, h. 174-180. Lihat M. Abdul Hamid, dkk., Pembelajaran Bahasa Arab: Pendekatan, Metode, Startegi, Materi dan Media, (Cet. I; Malang: UIN-Malang Press, 2008), h. 166-167.
} 
c. Prinsip korektsitas atau ketepatan (الدقة)

Artinya seorang guru dalam pemilihan media, metode dan strategi dalam pengajarannya tidak keliru sehingga peserta didiknya memudahkan mereka untuk mencerna dan memahami materi ajar. Seperti dalam pemebelajaran tarkib bisa dengan cara uslub tadribat namtiyyah (drill patterns).

d. Prinsip aspek motivasi (عنصر التشويق)

Untuk meningkatkan motivasi peserta didik dan tidak bosan dan jenuh dan belajar bisa dengan cara menggunakan metode dan strategi yang variatif. Di antaranya dengan cara metode bermain dn lain-lain.

e. Prinsip baku dan mendasar (الصلابة والمتانة)

\section{Urgensi Pembelajaran Efektif}

Muhammad Ali al-Khuliy, mengutarakan empat urgensi dari pembelajaran efektif, yaitu:

a. Pengajaran yang efektif berimplikasi terhadap belajar efektif.

b. Tanpa pengajaran efektif, maka peserta didik tidak bisa belajar secara efektif. Sehingga pengajaran efektif itu bukan hanya pemenuhan kebutuhan seorang guru melainkan juga terhadap peserta didik.

c. Pembalajaran yang efektif tercermin dalam ketercapaian tujuan pembelajaran dalam waktu secara efisien. Guru yang sukses adalah guru yang pandai memilih strategi pembelajaran yang bisa memberikan hasil yang optimal dalam waktu yang relatif singkat.

d. Belajar efektif, menumbuhkan kebahagiaan dan semangat peserta didik dalam belajar sehingga termotivasi untuk terus belajar dan prakarsa. ${ }^{29}$

\section{Standar Kompetensi Lulusan Bahasa Arab di Madrasah}

Untuk mewujudkan kompetensi lulusan secara efektif dan efisien. Maka guru dituntut untuk berusaha seoptimal mungkin, aktif, kreatif dan inovatif sehingga pembelajaran menjadi menyenangkan dan efektif dan akhirnya, membuahkan kualitas penguasaan bahasa yang baik dan benar. Adapun kompetensi lulusan bahasa Arab yang diharapkan sebagaimana tertuang dalam Keputusan Menteri Agama Nomor: 165 Tahun 2014, yang terangkum sebagai berikut:

a. Menyimak (al-Istima'), kemampuan memahami wacana lisan berbentuk paparan atau dialog tentang perkenalan, kehidupan keluarga, hobi, pekerjaan, remaja, kesehatan, fasilitas umum, pariwisata, kisah-kisah Islam, kebudayaan Islam, budaya Arab, dan hari-hari besar Islam.

b. Berbicara (al-Kalam), kemampuan mengucapkan secara lisan dalam bentuk paparan atau dialog tentang perkenalan, kehidupan keluarga, hobi, pekerjaan,

28 Amrah Kasim, Buku Panduan Perencanaan Program Pembelajaran Bahasa Arab Program Magister Pascasarjana UIN Alauddin Makassar, (Makassar: t.p., 2008), h. 10-13.

${ }^{29}$ Muhammad Ali al-Khuliy, Asalib Tadris al-Lughah al-'Arabiyyah, h. 33-34. 
remaja, kesehatan, fasilitas umum, pariwisata, kisah-kisah Islam, kebudayaan Islam, budaya Arab, dan hari-hari besar Islam.

c. Membaca (al-Qira'ah), kemampuan membaca dan memahami makna wacana tertulis paparan atau dialog tentang perkenalan, kehidupan keluarga, hobi, pekerjaan, remaja, kesehatan, fasilitas umum, pariwisata, kisah-kisah Islam, kebudayaan Islam, budaya Arab, dan hari-hari besar Islam.

d. Menulis (al-Kitabah), kemampuan mengungkapkan secara tertulis berbentuk paparan atau dialog tentang perkenalan, kehidupan keluarga, hobi, pekerjaan, remaja, kesehatan, fasilitas umum, pariwisata, kisah-kisah Islam, kebudayaan Islam, budaya Arab, dan hari-hari besar Islam. ${ }^{30}$

Di samping kompetensi lulusan tersebut di atas, M. Abdul Hamid dkk. Mengungkapkan bahwa pembelajaran bahasa Arab juga memiliki tujuan yang lain agar para peserta didik berkembang dalam hal:

a. Pengetahuan mengenai ragam bahasa bahasa dan konteksnya, sehingga para peserta didik dapat menafsirkan isi berbagai bentuk teks lisan maupun tulisan dan meresponnya dalam bentuk kegiatan yang beragam dan interaktif.

b. Pengetahuan mengenai pola-pola kalimat yang dapat digunakan untuk menyusun teks yang bermacam-macam dan mampu menerapkannya dalam bentuk wacana lisan dan tulisan.

c. Pengetahuan mengenai sejumlah teks yang beraneka ragam dan mampu menghubungkannya dengan aspek sosial dan personal.

d. Kemampuan berbicara secara efektif dalam berbagai konteks.

e. Kemampuan menafsirkan isi berbagai bentuk teks tulis dan merespon dalam bentuk kegiatan yang beragam, interaktif dan menyenangkan.

f. Kemampuan membaca buku bacaan fiksi dan non fiksi sederhana serta menceritakan kembali intisarinya.

g. Kemampuan menulis kreatif berbagai bentuk teks untuk menyampaikan informasi, mengungkapkan pikiran dan perasaan.

h. Kemampuan menghayati dan meghargai karya orang lain.

i. Kemampuan untuk berdiskusi dan menganalisis teks. ${ }^{31}$

Untuk mengetahui klasifikasi persentasi empat keterampilan dalam pembelajaran bahasa Arab tingkat menengah adalah, sebagaimana yang utarakan oleh Dr. Mahmud Ali Muhammad Syarabiy dalam penelitiannya, bahwa pelajar bahasa Arab sebagai bahasa kedua/asing dengan tujuan formal terbagi ke dalam tiga tingkatan, yaitu tingkat dasar (al-mustawa al-mubtadi), tingkat menengah (al-mustawa almutawasshith) dan tingkat tinggi (al-mustawa al-mutaqaddim). Untuk tingkat menengah, persentasi pendistribusiannya adalah keterampilan menyimak (istima') 35\%, keterampilan berbicara (al-tahadduts/al-kalam) 35\%, keterampilan membaca (al-

\footnotetext{
${ }^{30}$ Peraturan Pemerintah RI Nomor 19 tahun 2005 tentang Standar Nasional Pendidikan. Lihat juga Ahmad Fuad Mahmud Aliyan, al-Maharat al-Lughawiyyah: Mahiyatuha wa TharaiqTadrisiha, (Riyadh: Dar al-Muslim lin Nasyr wat Tauzi', 1992), h. 43-44.

${ }^{31}$ M. Abdul Hamid, dkk., Pembelajaran Bahasa Arab..., h. 159-160.
} 
qira'ah) 15\% dan keterampilan menulis (al-kitabah) sebanyak 15\%. Adapaun jumlah kosakata yang direkomendasikan sebanyak 1000 sampai 1500 kosakata. $^{32}$

Tabel. Persentasi Distribusi Keterampilan Berbahasa ${ }^{33}$

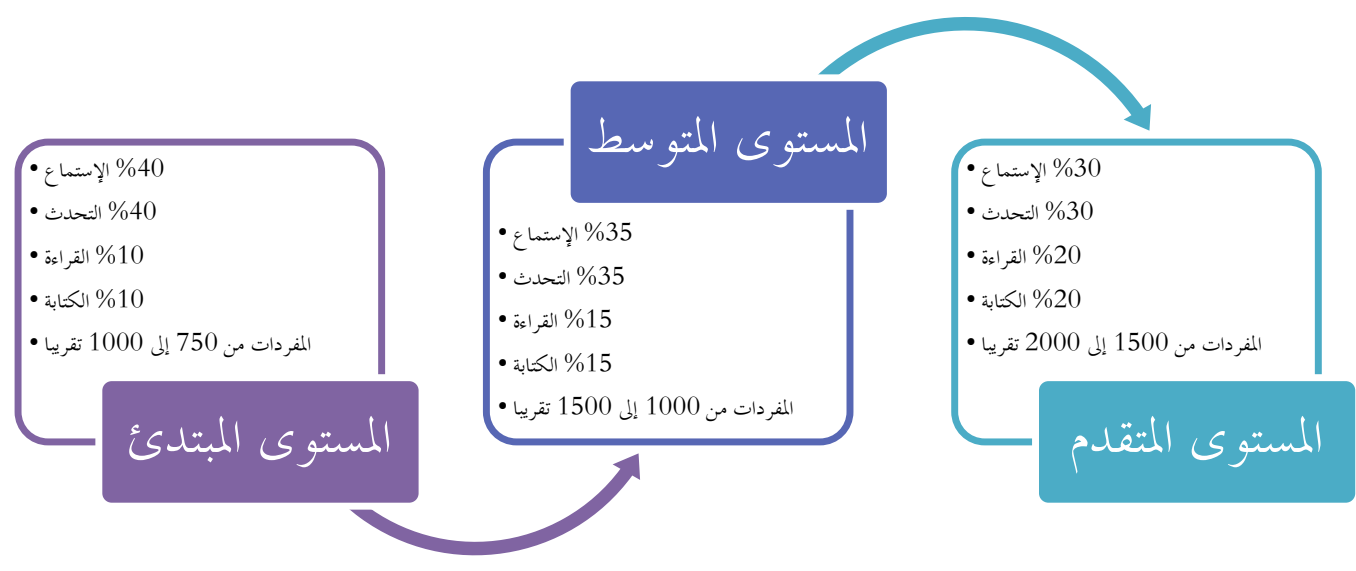

\section{Simpulan}

Pembelajaran efektif merupakan suatu proses pembelajaran yang bersifat holistik. Disamping tujuannya untuk perubahan prilaku peserta didik (behavior) ke arah yang lebih baik, juga pencapaian tujuan instruksional pembelajaran yang telah digariskan sebelumnya secara terukur dan efisien. Sederhananya bahwa pembelajaran efektif adalah pembelajaran yang efisien dengan tercapainya tujuan yang telah ditetapkan. Kalau konteksnya dibawa ke dalam ranah pengajaran bahasa Arab, maka tujuan standar instruksional yang dimaksud adalah tujuan kompetensi lulusan bahasa Arab yang empat yaitu kemampuan menyimak (alistima'), berbicara (al-kalam), membaca (al-qira'ah), dan menulis (al-kitabah).

Konsep pembelajaran efektif adalah yang pusat pembelajarannya terfokus pada peserta didiknya (student centered). Dan di antara indikator proses pembelajaran yang dapat dikatakan berhasil atau efektif adalah apabila kegiatan pembelajaran tersebut dapat membangkitkan proses belajar terhadap peserta didiknya. Jadi tolak ukurnya adalah terletak pada out put-nya. Guru merupakan kunci dalam keberhasilan dan keefektifan sebuah pembelajaran. Guru tidak hanya dituntut untuk mentransfer informasi dan pengetahuan di kelas melainkan juga menjadi tenaga pendidik untuk mengasah soft skill peserta didik sekaligus memotivasinya untuk mendongkrak semangat dirinya agar mau belajar dan belajar melakukan, sehingga pembelajaran menjadi hidup, aktif, interaktif dan efektif.

Adapun klasifikasi persentasi empat keterampilan dalam pembelajaran bahasa Arab tingkat menengah adalah keterampilan menyimak (istima') sebanyak 35\%, keterampilan berbicara (al-tahadduts/al-kalam) sebanyak 35\%, keterampilan membaca (al-qira'ah)

${ }^{32}$ Mahmud Ali Muhammad Syarabiy, Istratiyjiyyah Muqtarahah Qaimah 'ala Madkhal al-Taqabuli al-Lughawiy wa Thalil al-Akhtha' fi Tanmiyah Maharat al-Fahmi al-Istima'iy wal Qira'ah al-jahriyyah wal Kitabah al-Wadhzifiyah laday Darisiy al-Lughah al- 'Arabiyyah al-Natiqinan bi Ghairiha, Risalah Dukturah. (Ma'had al-Dirasat al-Tarbawiyyah, Jami'ah al-Qahirah, 2011)., h. 179.

${ }^{33}$ Mahmud 'Ali Syarabiy, Dalil Muta'allimiy al- 'Arabiyyah lin Nathiqiyna bi Ghayriha, (Riyadh: Dar Wojooh lin Nasyir wat Tauzi', 2015)., h. 26. 
sebanyak $15 \%$ dan keterampilan menulis (al-kitabah) sebanyak 15\%. Adapaun jumlah kosakata yang direkomendasikan sebanyak 1000 sampai 1500 kosakata. ${ }^{[]}$

\section{Daftar Rujukan}

al-Ahwani, Ahmad Fuad, al-Tarbiyyah al-Islamiyyah aw al-Ta'lim fi Ra'yi al-Qabisi, Kairo: Dar Ihya al-Kutub al-'Arabiyyah, 1955.

Asmani, Jamal Ma'mur, Tips Menjadi Guru Inspiratif, Kreatif dan Inovatif, Cet. VI; Jogjakarta: DIVA Press, 2010.

al-Dailamiy, Thaha Ali Husain, dan Sa'ad Abdu al-Karim al-Wailiy, al-Lughah al'Arabiyyah: Manahijuha wa Tharaiq Tadrisiha. Cet. II; Oman: Dar al-Syuruq, 2005.

Hamalik, Oemar, Kurikulum dan Pembelajaran, Jakarta: Bumi Aksara, 1995.

Hamid, M. Abdul, dkk., Pembelajaran Bahasa Arab: Pendekatan, Metode, Startegi, Materi dan Media, Cet. I; Malang: UIN-Malang Press, 2008.

Kasim, Amrah, Buku Panduan Perencanaan Program Pembelajaran Bahasa Arab Program Magister Pascasarjana UIN Alauddin Makassar, Makassar: t.p., 2008.

Keputusan Menteri Agama nomor 165 tahun 2014.

al-Khuliy, Muhammad Ali, Asalib Tadris al-Lughah al-'Arabiyyah, Cet. III; Riyadh: alMamlakah al-'Arabiyyah al-Sa'udiyyah, 1989.

Muhaimin, dkk., Strategi Belajar Mengajar, Surabaya: CV. Citra Media, 1996.

Muslim, Konfigurasi Pemikiran Al-Qabisi tentang Pendidikan Islam, dalam Potensia: Jurnal Kependidikan Islam. Volume 2, Nomor 2, 2016, 199-211.

Nasution, S., Didaktik Asas-asas Mengajar. Cet. I; Jakarta: Bumi Aksara, 1995.

Parera, Jos Daniel, Linguistik Edukasional: Metodologi Pembelajaran Bahasa, Analisis Kontranstif Antar Bahasa, Analisis Kesalahan Berbahasa, Ed. II; Jakarta: Erlangga, 1997.

Peraturan Pemerintah RI Nomor 19 tahun 2005 tentang Standar Nasional Pendidikan.

Supardi, Sekolah Efektif: Konsep Dasar dan Praktiknya, Jakarta: Rajawali Pers, 2013.

Syarabiy, Mahmud Ali Muhammad, Istratiyjiyyah Muqtarahah Qaimah 'ala Madkhal alTaqabuli al-Lughawiy wa Thalil al-Akhtha' fi Tanmiyah Maharat al-Fahmi alIstima'iy wal Qira'ah al-jahriyyah wal Kitabah al-Wadhzifiyah laday Darisiy alLughah al- 'Arabiyyah al-Natiqinan bi Ghairiha, Risalah Dukturah. Ma'had al-Dirasat al-Tarbawiyyah, Jami'ah al-Qahirah, 2011.

Syarabiy, Mahmud Ali, Dalil Muta'allimiy al-'Arabiyyah lin Nathiqiyna bi Ghayriha, Riyadh: Dar Wojooh lin Nasyir wat Tauzi', 2015.

Tim Penyusun Kamus Pusat Bahasa, Kamus Bahasa Indonesia, Jakarta: Pusat Bahasa, 2008.

Uno, Hamzah B., Teori Motivasi \& Pengukurannya: Analisis di Bidang Pendidikan. Cet. II; Jakarta: Bumi Aksara, 2007.

Uno, Hamzah B., dan Nurdin Mohamad, Belajar dengan Pendekatan PAILKEM, Cet. II; Jakarta: Bumi Aksara, 2011.

Yasin, Salehuddin, Metode Belajar dan Pembelajaran yang Efektif, dalam Jurnal Adabiyyah. Volume 12, Nomor 1, 2012, 1-9.] 